\title{
Over my dead body! media constructions of forced prostitution in the People's Republic of China
}

\author{
Elaine Jeffreys, University of Technology Sydney
}

In late 1997, 24-year-old Tang Shengli became a household name in the People's Republic of China (PRC) after she threw herself out of a six-metre high window to escape being forced to sell sexual services in a nightclub. Her actions, which resulted in first-degree spinal damage, are now immortalized in a Chinese dictionary. The dictionary defines a new term, sanpeinü, as referring to an illicit form of female worker, namely, a 'hostess' who accompanies men to sing, drink, and dance, in public entertainment venues, and is often associated with the provision of commercial sexual services. Explaining how to apply this term, the dictionary states: 'This year the case of Sichuanese rural migrant worker, Tang Shengli, who jumped from a building saying "I would rather die than become a 'hostess'”, made a sensation' ('Xinhua xin ciyu cidian ye “bao” ernai’ 2002).

The Chinese media has since covered more than 30 cases of women who have followed Tang's example. ${ }^{1}$ These women are reified by some sectors of the Chinese media as resistant heroines or new millennium female chastity martyrs (lienü), that is, as women who are prepared to terminate their lives in order to defy 'masculine oppression', but whose virtue lies as much in their old-fashioned determination to defend their 'virginity and reputation' as in their modern-day 'feistiness and strong will' (Sun 2004, 114). Hence, other commentators have criticized this focus for

\footnotetext{
${ }^{1}$ Wang Yueguo (2003) refers to 22 cases by 2003. I am aware of more than nine cases since that time. For details of other cases, see Dai and Liu 2000; Gong 2002; Guangzhou lienü Liu Qinqin zuo dedao lianhe fayuan” 2005; Li and Li 2004; Li Xiaobo 2002; Lin 2004; Liu and Zhang 2001; Meng 2000; Pu 2004; Ran and He 2004; Su 2001; Wan and Liu 2004; and Zhang 2004.
} 
endorsing Confucian or feudal-patriarchal conceptions of the ideal (virtuous) woman, and for contributing to the longstanding cultural denigration of women-in-prostitution by eliding the male side of demand and suggesting that those who sell sex in a voluntary capacity are truly ‘fallen women’ (Sun, 2004, 114-16; He 1998; Lü 2001; Wang Xiaobo 2002).

This paper examines some of the tensions surrounding the PRC's official policy of banning prostitution by focusing on two highly publicized cases of deceptive recruiting for sexual services - the 'Tang Shengli Incident' and the 'Liu Yanhua Incident'. Both cases involved young rural women who had migrated from their native homes to other more economically developed parts of China to look for work. Both women were required to sell sex and both resisted. However, whereas Tang Shengli jumped from a building rather than be forced into prostitution, Liu Yanhua escaped from conditions akin to sexual servitude by physically assaulting her 'employer'. An examination of these cases highlights some of the problems associated with efforts by the Chinese women's media to protect and promote women's rights in a country marked by rapid, yet unequal, economic growth and an expanding, albeit banned, sex industry.

\section{Publicizing the 'Tang Shengli incident'}

Prostitution comprises a new object of governmental concern in the PRC in that following its assumption of political power in 1949, the Chinese Communist Party (CCP) embarked upon a series of campaigns that purportedly eradicated prostitution from the mainland by the late 1950s (Jeffreys 2004, 96). The extraordinary nature of this feat, irrespective of its actual validity, meant that the eradication of prostitution was (and still is) vaunted as one of the major accomplishments of the new regime. Indeed, a Chinese government white paper describes it as effecting an 'earth-shaking historic change in the social status and condition of women' ('Historic liberation of Chinese women’ 2000). Following Engels ([1884] 1972), the early CCP viewed the institution of prostitution as an expression of the exploited and denigrated position of women under capitalism-patriarchy, and hence as incompatible with the desired goals of building socialism and establishing more equitable socio-sexual relations. Since the early 1980s, however, along with the shift from a planned to a market economy, China's governmental authorities have acknowledged that the phenomenon of 
prostitution has not only reappeared on the mainland, it also constitutes a widespread and growing problem. In fact, it is now considered that the introduction of new laws and regulatory measures has failed to curb the prostitution business, especially its proliferation throughout China's new and burgeoning hospitality and service industry (Jeffreys 2004, 96-102).

The story of Tang Shengli thus bears recounting because it is the first widely publicized case in economic-reform China of a woman who was prepared to risk her life rather than be forced into selling sexual services in a nightclub. In keeping with the labour mobility demanded by market-based reforms, ${ }^{2}$ on 23 November 1997 Tang Shengli, the 24-year-old daughter of a poor coalminer from Wangcang County in Sichuan Province, and her friend, Jiang Hongmei, traveled approximately $300 \mathrm{~km}$ from their native homes to a labour market in Chengdu City to look for work ('Lienü Tang Shengli Chengdu xinhun’ 2004). ${ }^{3}$ The two women were approached by what appeared to be a married couple with two teenage girls, who offered them employment as waitresses in a restaurant for 300 yuan per month, plus accommodation and food. The presence of the teenagers, combined with the fact that the proposed salary was around three times more than they might expect to receive from working closer to home, persuaded Tang and Jiang that it was both safe and appropriate to accept employment with Hu Shuiyuan, a man in his 40s. However, upon their arrival at the Tianya nightclub in Meishan County, approximately $150 \mathrm{~km}$ from Chengdu, they discovered that they were expected to work as hostesses. The two women refused but were kept under close personal surveillance, forced to watch pornographic videos as an instruction for prostitutional sex, ${ }^{4}$ and obliged to accompany male patrons of the venue, all of whom expressed no interest in them,

\footnotetext{
${ }^{2}$ During the Maoist period (1949-1976), and for some time after, Chinese citizens were geographically fixed to their place of abode in order to suit the requirements of centralized planning, hence labour mobility is a new feature of the post-1978 or economic reform period. For a discussion of the impact of this mobility on rural Chinese women, see Gaetano and Jacka (eds), 2004.

${ }^{3}$ Labour markets are gathering places for employers and their agents and people who are looking for work. Employers often want skilled or semi-skilled labour, whereas a significant number of people who attend such markets are looking for unskilled work in the hospitality and service industry, for example, as domestic maids, factory workers, garbage collectors and construction workers. Despite efforts to regulate China's labour markets, both unskilled migrant workers and 'unregistered' agents and employers continue to use these markets as an informal meeting place, primarily by avoiding official registration fees and checks and simply moving around the busy venues to look for potential workers and employers (Sun Guangxun 2005).

${ }^{4}$ The production and dissemination of pornography is prohibited in China, but pornographic materials are increasingly available.
} 
preferring the company of other women in the nightclub. After two days of being afraid and confined in this fashion, Tang attempted to escape by leaping from a window on their first-floor sleeping quarters, ${ }^{5}$ with the result that she became paralyzed from the waist down. Jiang reportedly intended to jump after Tang but desisted when she saw that her friend had sustained serious injuries ('Lienü Tang Shengli Chengdu xinhun’ 2004; Tan 1998).

Following local media coverage, Tang Shengli's story became national news on 27 December 1997 when the All China Women's Federation (ACWF) published an article entitled 'The 'Tang Shengli Incident' shocks Chengdu', in its media flagship, the China Women's News (Zhongguo funü bao), a weekly paper with a circulation of 110,000 copies. The ACWF was founded by the CCP in 1949 and is charged with the task of representing and safeguarding women's rights and interests and promoting equality between women and men. Although the feminist credentials of the ACWF are often disputed, due to its historic and continued role in promoting the goals of the Chinese party-state, it remains the largest and most influential organization working for the protection and promotion of women's rights in the PRC, acquiring consultative status with the United Nations Economic and Social Council in 1995 (Hsiung et al. 2001). The editorial staff at the China Women's News turned Tang Shengli into a national heroine by making her the focus of a small-scale media campaign designed to attack the resurgent phenomenon of prostitution (especially its rapid expansion in the form of the provision of hostess services throughout China's hospitality and service industry), and thereby garner public support for the official policy of banning it ( $\mathrm{Wu}$ 2003).

Organizing, inducing, introducing, facilitating, or forcing, another person to engage in prostitution is a criminal offence in China, punishable by up to five or up to 10 years imprisonment with the possible addition of a fine, according to the PRC's first criminal code, promulgated on 1 January 1980, and the revised 1997 Criminal Code of the People's Republic of China (see Articles 358-9, 1998). Although first-party participation in the prostitution transaction is not criminalized, it is banned on the

\footnotetext{
${ }^{5}$ Here, I am using the Australian and British practice of counting the number of floors in a multi-storey building by commencing with the ground floor, followed by the first floor, second floor, and so on. In China, as in the USA, the ground floor is described as the first floor. Hence in Chinese-language accounts, Tang Shengli jumped from a second-storey window.
} 
basis of legislation that the ACWF helped to formulate, namely, the 1991 Decision on Strictly Forbidding the Selling and Buying of Sex, and the 1992 Law on Protecting the Rights and Interests of Women (Quanguo renda changwu weiyuan hui 1991; Zhonghua renmin gongheguo hunyin fa, Zhonghua renmin gongheguo funü quanyi baozhang fa 1994). These laws ban engagement in and facilitation of the prostitution transaction as a social harm and a violation of the rights of 'woman-as-person', punishable by a maximum of 15 days detention for investigation and the possible addition of a fine; and, in more serious cases, by between six months and two years detention for reform through education and/or labour with the possible addition of a fine, according to stipulations outlined in the former Chinese system of administrative sanctions.

The Chinese system of administrative sanctions came into being during the Maoist period (1949-1976), when the legal system fell into disrepute as a tool of class-based oppression. Following the promulgation of the PRC's first criminal code in 1980, it was used, and not without criticism, alongside the formal legal system to police the activities of those who were deemed to have committed social offences, but whose criminal liability was not deemed sufficient to bring them before the courts (Starr 2001: 204-19). This meant that the vast majority of prostitution-related offences-i.e., the processes of investigating, determining guilt, and suitably penalizing, the activities of sellers and buyers of sex-were handled by China's public security agencies, with only serious cases, such as those relating to the organization of prostitution, forced prostitution, and trafficking in women and children, being handled through the courts and criminal justice system. The PRC's new Security Administration Punishment Law of 1 March 2006 continues to ban first-party engagement in the prostitution transaction as a social harm, but it significantly reduces previous penalties. It states that offenders may be punished by a maximum of five days administrative detention or a fine of 500 yuan; and, in more serious cases, by 10 to 15 days administrative detention with the possible addition of a fine up to 5,000 yuan (Quanguo renda changwu weiyuanhui 2005). Hence, the emerging body of Chinese prostitution law can be technically described as abolitionist not prohibitionist in that it criminalizes third-party involvement in the running of prostitution businesses, rather than firstparty participation in the prostitution transaction (Jeffreys 2004: 138-49). 
In keeping with the abolitionist impetus of Chinese prostitution law, the China Women's News proceeded to publish an estimated 24 reports that upheld Tang Shengli as embodying the perceived spirit of Chinese women-their resilience, self-respect and refusal to be downtrodden — and attacked the resurgent prostitution industry for encouraging violations of women's rights (Wu 2003). Hampered by complaints from government authorities in Sichuan that their focus on Tang was promoting an unnecessarily bad image of the province, the ACWF published a series of localized case studies that exposed the links between forced prostitution and the provision of hostess services across the nation (Wu 2003). Articles entitled 'Hostessing Has To Be Stopped', 'Women's Dignity Should Not Be Violated', and 'Labour Markets Are In Need of Regulation', focused on the plight of vulnerable young women from poor agricultural provinces, who had been recruited, either in their native villages or at labour markets, by people offering comparatively well-paid work as waitresses and receptionists in the urban hospitality and service industry (Wu 2003). As with Tang Shengli, many had arrived to discover that they had been deceived about the nature of the work they were expected to perform. Their recruiters had then used a variety of means to prevent the women from leaving, such as threats, beatings, rape, and forcing them to sign promissory notes akin to debt-bondage to cover the costs of their travel and accommodation, i.e., debts that could only be paid off by their engagement in prostitution. Additionally, their recruiters had not only withheld the women's personal identity cards, thereby depriving them of the ability to leave and gain a legitimate livelihood elsewhere in China, ${ }^{6}$ but also ensured that their victims would be reluctant to seek help by playing on their physical dislocation, lack of finances and social connections, and the shame that would follow from public knowledge of their situation (Wu 2003). Thus, while occurring within China’s domestic borders, the situation of these women conforms to international definitions of the crime of trafficking in persons for the purposes of sexual exploitation. ${ }^{7}$

\footnotetext{
${ }^{6}$ In China, internal migrants who lack identity cards and proper documentation, stable residence, or secure employment, can find themselves the focus of police attention and may even be detained for police investigation. For a discussion of this issue see Gaetano and Jacka eds, 2004: 14-20.

7 The United Nations Convention against Transnational Organized Crime and the Protocol to Prevent, Suppress and Punish Trafficking in Persons, especially Women and Children, defines people trafficking as the: 'recruitment, transportation, transfer, harbouring or receipt of persons, by means of the threat or use of force or other forms of coercion, of abduction, of fraud, of deception, of the abuse of power or of a position of vulnerability or of the giving or receiving of payments or benefits to achieve the consent of a person having control over another person, for the purpose of exploitation. Exploitation shall include, at a minimum, the exploitation of the prostitution of others or other forms of
} 
By focusing on the links between deceptive recruiting for sexual services and the provision of hostess services, the ACWF suggested that local-government authorities were insufficiently committed to the combined task of safeguarding women's rights and eradicating the prostitution industry. This suggestion was buttressed with reference to the perceived failure of law enforcement authorities to punish traffickers and organizers of prostitution businesses according to the full letter of the law. For example, Hu Shuiyuan, the man who recruited Tang Shengli, initially was not penalized on the basis of criminal sanctions, but rather in accordance with the theoretically more lenient provisions outlined in the Chinese system of administrative sanctions. On 31 December 1997, Hu’s business license was revoked and he was sentenced to one year of re-education through labour for keeping women in prostitution ('Lienü Tang Shengli Chengdu xinhun’ 2004, 1). Media outcry over the seeming leniency of this sentence, which the ACWF actively encouraged, resulted in Hu's case being re-opened for investigation and potential handling by the criminal courts. Consequently, on 28 September 1998, the Local People’s Court in Meishan County imposed a sentence of five years jail and a fine of 5,000 yuan on Hu Shuiyuan for illegally operating a prostitution business (Hou 2004; Jiang 1998, 3).

Apart from demanding criminal penalties for organizers of prostitution businesses, the ACWF's promotion of the 'Tang Shengli Incident' aimed to counter local government quiescence by garnering support for the introduction of new legislation designed to halt the provision of hostess services in recreational venues. During 1997-8, the question of whether or not 'hostessing' should be tolerated in order to develop local tourism and leisure industries, as well as to generate much-needed local government revenue, attracted considerable controversy in the Chinese media (Fan 2002). This controversy centred on the decision of certain municipal authorities to levy individual income tax on women who derived an income from 'tips', service fees, or informal consumption taxes, in entertainment venues. Representatives from local government and tax departments justified their actions by arguing that prostitution and hostessing were fundamentally different in nature (Wang Fengbin 1998). Whereas prostitution

sexual exploitation, forced labour or services, slavery or practices similar to slavery, servitude or the removal of organs' (Article 3a, United Nations 2000). 
constituted a social harm, hostessing simply referred to the provision of (voluntary) dancing and singing companions, in venues that are predominantly patronized by private businessmen and male government officials, due to the high consumption costs involved. Proponents of this view further insisted that they were obliged by the PRC's taxation laws to levy individual income tax on citizens who met the tax threshold criteria; but they were not required to determine whether that income was legally generated (Wang Fengbin 1998). As far as the ACWF and China's public security agencies were concerned, these actions complicated the already difficult task of policing the 'grey area' between the provision of hostess services and prostitution, because it granted a quasi-legal status to the activities of hostesses by treating them as equivalent to any other citizen-as-worker.

In consequence, the ACWF submitted a report to China's main legislative body, the National People’s Congress, requesting stricter controls over commercial recreational enterprises and clarification of the duties of all relevant departments with regard to the control of prostitution businesses (Jeffreys 2004, 145-7). Although ACWF representatives originally maintained that this proposed initiative would not directly affect women who merely accompanied male patrons of recreational venues, they also insisted that stricter controls were necessary to deter the provision of sex-related hostess services by leading to a renewed crackdown on prostitution ('Women's lobby tackles bar sex' 1999). The ACWF's request was supported by similar requests from China's public security agencies, on the grounds that the indeterminate nature of hostess services, combined with the emergence of new kinds of commercial sexual practices, had made the task of policing prostitution virtually impossible. In fact, as far as China's public security agencies were concerned, the quasi-acceptance of hostess services abetted prostitution by encouraging the practice of 'accompanying first and engaging in prostitution later', a practice that simultaneously evaded official prostitution controls, whilst financially benefiting the owners of recreational business enterprises (Jeffreys 2004, 147).

The ACWF's successful lobbying of the National People’s Congress resulted in the promulgation of the 1999 'Regulations concerning the management of public places of entertainment' (hereafter the Entertainment Regulations) (Zhonghua renmin gongheguo guowuyuan 1999). These regulations turn on the understanding that 
prostitution and the provision of hostess services are indivisible, with the latter not only constituting a 'breeding ground' for prostitution, but also encouraging corruption in the form of local government collusion in the running of prostitution businesses, and the widespread expropriation of public funds by male government officials to wine, dine and buy the services of women in recreational venues (Fan 2002). The Entertainment Regulations therefore forbid all forms of commercial sex-related activities in recreational enterprises by stipulating that anyone who participates in, promotes or profits from, and/or fails to report the existence of such activities, will be made subject to criminal or administrative penalties (Zhonghua renmin gongheguo guowuyuan 1999). They further aim to restrict the available pool and turn-over of labour within China's hospitality and service industry by reinforcing the longstanding stipulation that all personnel must possess a residency permit, or a temporary work and residency permit, and hence be 'known' to the local police. Police-led campaigns directed at controlling illicit business operations and the provision of hostess services subsequently were implemented throughout the PRC in late 1999 and 2000 , resulting in the closure of nearly one million recreational businesses operations of miscellaneous forms, even though they failed to eradicate prostitution and hostessing activities in toto (Jeffreys 2004, 177-9).

The ACWF also promoted the 'Tang Shengli Incident' to demonstrate that victims of sexual exploitation require public and state assistance. This goal was realized through its coordination with other governmental departments, news agencies, and legal specialists, and ultimately with the Chinese Rehabilitation Research Centre at the prestigious Bo Ai Hospital in Beijing, which offered Tang free medical treatment as part of its own public relations campaign (Hou 2004). Upon hearing of Tang's predicament and reportedly inspired by her moral courage, representatives from the Centre contacted the China Women's News to ask for its assurance, as a CCPaffiliated organization, that the facts of the case were authentic (Zhongguo kangfu yanjiu zhongxin 2003). Once it was established that Tang and her family were unable to pay for either continuing or specialist medical care, Tang was invited to come to the Centre for free rehabilitative treatment, including the cost of accommodation, drugs and food, as well as financial support for her visiting family. The pay-back for the Centre was Tang's agreement to become the focus of a nationwide media blitz designed to improve the Centre's public visibility and attract more clients, thereby 
improving its financial viability, as necessitated by the removal of state-funding in the privatized era of economic reform.

In what proved to be an award-winning public relations exercise, Tang Shengli arrived in Beijing on the evening of 6 January 1998 and was duly met by a welcoming committee of representatives from the Chinese Rehabilitation Research Centre and over 20 news agencies (Zhongguo kangfu yanjiu zhongxin 2003). Photographs of this reception and a prepared news statement entitled, 'The Chinese Rehabilitation Research Centre Offers to Treat and Cure Tang Shengli, the Woman Who Was Willing to Die Rather Than Become a "Hostess”, , were publicized and televised throughout the nation. During Tang's four-month stay at the Centre, a wide range of senior government officials paid her formal visits that attracted ongoing media coverage, including senior representatives from the ACWF and China's Disabled Federation. Additionally, the Centre received thousands of letters and money donations from members of the public, and donations from overseas pharmaceutical companies. Despite initial doubts over Tang's capacity to walk again, by the end of her stay, she was able to walk with the aid of supports and manage her own daily needs. In conjunction with the ACWF, the Centre also organized skills training for Tang to learn how to knit and realize a livelihood upon her departure, giving her a parting gift of 10,000 yuan and a knitting machine valued at 8,000 yuan. As with her arrival, Tang's discharge from the Centre on 15 May 1998 was accompanied by a large press conference, involving 38 news agencies and more than 50 reporters, and an elaborate farewell ceremony.

The Chinese Rehabilitation Research Centre subsequently won a commerce and industry prize in 2003 for one of the most successful public relations exercises conducted by a government and non-profit organization in reform-era China, since the national media reported on Tang Shengli’s case approximately 120 times, and the Centre attracted a significant number of patients on the basis of that coverage (Zhongguo kangfu yanjiu zhongxin 2003). In fact, the Centre capitalized on Tang's media currency throughout late 1999 and early 2000 by offering similar help to Dong Shujun, a 23-year-old woman from a poor rural family in Changshou County, Chongqing Municipality, who was deceived about the nature of her employment in May 1999. Dong was raped because she refused to engage in prostitution, suffered 
paralysis in her lower limbs following a failed attempt to escape by leaping out of a window, and then was recaptured and gang-raped before being set free (Deng Hongyang 2001).

The interest of Party and government organizations other than the ACWF in cases such as that of Tang Shengli suggests that media constructions of China's 'new millennium female chastity martyrs' serve a variety of purposes, not strictly the ACWF's goal of promoting the PRC's official ban on prostitution. This point is highlighted by the case of Hong Zhaodi. In June 1998, Hong Zhaodi, a twenty-yearold woman from a village in Suxian County, Anhui Province, was admitted to hospital after being badly beaten for refusing to engage in prostitution and having been deceived about the nature of her employment. When hospital staff ignored Hong's requests to call the police and her 'employer' came to collect her, she jumped in desperation from a second-storey window, resulting in first-degree spinal damage (Cai and Yuan 2005; 'Jiuzhi tekun bingren’ 2005). As with the Chinese Rehabilitation Research Centre's promotion of Tang Shengli, Hong's case was made the focus of a public relations exercise designed to highlight the importance of humanitarian cooperation between different Party and government departments, as well as the general public. For example, due to the personal intervention of the secretary of the Guangdong Provincial Government, Hong, as a poorly educated, rural migrant worker, was given the extraordinary opportunity to engage in higher education and to join the Communist Party. Her ultimately successful physical rehabilitation also received widespread publicity in the Guangzhou Evening News, initially to elicit public donations to help with Hong's medical expenses, and later as part of public health campaign entitled '100 Party Members Give Special Medical Treatment to 100 Needy Cases’ ('Jiuzhi tekun bingren’ 2005). Hence, although the China Women’s News played an instrumental role in promoting the 'Tang Shengli Incident', media constructions of Tang Shengli and other women as 'new millennium chastity martyrs' perhaps owe as much to the utility of tragedy and moral outrage as a means of promoting charity and benevolence towards those sidelined by China's increasingly privatised and cash-strapped public health system, as they do to the ACWF's historical and continued opposition to prostitution. 


\section{Debating the 'Tang Shengli incident'}

Chinese media accounts of Tang Shengli tend to celebrate a tale of personal success in the face of extreme adversity and the utility of cooperation between different government agencies in the changed era of economic reform. To begin with, the ACWF's active coordination with other governmental agencies, including news agencies, legal specialists, and ultimately the Chinese Rehabilitation Research Centre, helped to realize at least two goals outlined in international conventions on preventing trafficking in women for the purposes of forced prostitution and sexual servitude (a situation wherein the use of force and threats prevent a person from ceasing to provide sexual services or leaving the place where those services are performed). United Nation protocols on the prevention of trafficking in persons contend that states shall consider measures to provide for the physical, psychological and social recovery of victims of trafficking, in part, by providing victims with medical, psychological, and material assistance (United Nations 2000). States are further enjoined to promote a greater awareness of people-trafficking matters in the general community, primarily by working with the media in order to encourage responsible reporting of the subject. The ACWF clearly advanced both of these objectives by making Tang Shengli the focus of a small-scale media campaign designed to oppose the resurgent prostitution industry.

In addition, personal testimonies from Tang Shengli praise the role played by the ACWF and the Chinese media in ensuring her physical and social recovery. Tang became the focus of national headlines once again in January 2004, when the China Women's News reported on her marriage to Luo Qijia, a 39-year-old former security guard, in the Xinguang Hotel of Chengdu City. At the reception, Tang thanked attending representatives from the ACWF and the Chinese media as a whole for giving her a 'second shot at life' (Hou 2004). During the period of her hospital treatment in Beijing, Tang had told reporters that one of her few remaining regrets was that she would probably remain single due to the long-term consequences of her injuries (Tan 1998). These included bowel dysfunction, ongoing medical expenses, and presumably an inability to bear children. However, upon her eventual release, Tang had abandoned the anticipated source of her income - the knitting machineand started looking after a small convenience store run by her step-mother, which proceeded to attract a reasonable business, chiefly on the basis of her public 
reputation. Concomitantly, Luo had written to Tang after being inspired by media accounts of her heroism; and, following six years of mutual correspondence and various meetings, the couple had decided to wed (Hou 2004; 'Lienü Tang Shengli Chengdu xinhun’ 2004).

But the fact that more than 30 Chinese women have followed Tang Shengli's example has generated criticisms of the media strategy of reifying such women as modern-day chastity martyrs-cum-heroines. A major complaint is that this focus inadvertently reinstates the traditional cultural value on female virginity in China, and the ensuing stress on monogamous, heterosexual marriage, by implying that chastity is more important than life (Lian 2002; Lü 2001; Wang Xiaobo 2002; Wang Yueguo 2003; Zhou 2002). In doing so, it suggests that women who find themselves at risk of rape and/or being forced into prostitution should act in the same manner as Tang, chiefly by failing to provide any alternative strategies. Critics further aver that the individualized focus on such women as 'chastity heroines' entrenches the 'whore stigma' by giving implicit support to the broader media representation of women who prostitute or hostess in a voluntary capacity as ‘fallen women'. In the process, it deflects critical attention away from a serious consideration of the broader socioeconomic factors that encourage the existence of prostitution businesses and practices in China today (He 1998; Pan 2003; Sun, W. 2002: 109-28). Compounding these problems, a recent survey on 'women and the media' suggests that the most disliked category of media reporting according to female respondents is the topic of female chastity martyrs (Li and Wang 2003: 7; Sheng 2003). Critics thus conclude that the professed goal of the so-called women's media in China-to improve legal protections for women, especially for rural migrant women-might be better achieved by denouncing the existence of forced prostitution and simultaneously challenging the traditional value accorded to female chastity and 'ideal' womanhood (Sheng 2003; Zhou 2003).

These complaints are often and somewhat erroneously directed at the ACWF as a perceived 'mouthpiece' for moralistic Party-state rhetoric and a 'failed' voice for women’s issues in China (Sun, W. 2004: 109-28; Zheng 2004: 97). I say 'erroneously' in that journalists associated with the ACWF are responsible for raising precisely the same issues that are used to criticize the organization. For example, the 
Women's Media Watch, a media-monitoring group that was established with the active involvement of the ACWF, explicitly criticizes what it describes as the mainstream media's tendency to eulogize Tang Shengli and women in similar circumstances as female chastity martyrs (Cai et al. 2001: 216-17). As the group notes, this focus reinforces patriarchal conceptions of women and fails to promote new understandings of women's rights as human rights, by emphasizing the 'innocence' of the women in question, rather than the fact that their health, life, and freedom, were being abused (see also Lü 2001; Wang Xiaobo 2002). Other commentators associated with the ACWF further contend that the strategy of focusing on female chastity martyrs is problematic because it contributes to the historical elision of the male side of the demand for prostitution, and deflects attention away from the more serious question of exactly who demands the services of female sex sellers in the first place, i.e., men with money and power (Bo 2001; He 1998). These criticisms suggest that ACWF-affiliated journalists believe that their promotion of the 'Tang Shengli Incident' as an example of the need to combat sexual exploitation and violence against women was co-opted by the broader media and turned into a personalized tale of 'chastity martyrdom', even as it does not exclude the possibility that this complaint may have been targeted at sectors of the ACWF from within the ACWF itself. At the very least, it suggests that it is analytically unproductive to treat the ACWF as a unitary 'mouthpiece' for Party-state rhetoric, and therefore as an organization that promotes 'false' and 'unfeminist' approaches (i.e., approaches that always compare negatively with those proffered by something arbitrarily designated as an 'unofficial' and more 'socially responsible' sector of the commercial Chinese media).

The misguided nature of some criticisms of the ACWF's promotion of the 'Tang Shengli Incident' is highlighted by debates surrounding the previously mentioned survey on women and the media. Some commentators explicitly cite this survey to criticize what they describe as the focus of the women's media on Tang Shengli and women in similar circumstances as female chastity martyrs (Li and Wang 2003: 7; Sheng 2003). They further contend that the erroneous underpinnings of such a focus are patently obvious since the most disliked topic of media reporting on the part of female respondents was ‘female chastity martyrs' (Li and Wang 2003: 7; Sheng 2003). One problem here is that the same survey indicates that an equally disliked 
category of media reporting on the part of female respondents was the subject of domestic violence ( $\mathrm{Li}$ and Wang 2003: 7). Given the absence of any additional information as to why female respondents dislike media coverage of such topics, or even what topics they could choose to 'like' or 'dislike', that professed disdain may owe more to feelings of abhorrence at the flagrant abuse described in media coverage of such cases than its problematic underpinnings. Likewise, it is not clear what exactly is meant by the 'women's media', even though it presumably refers to the China Women's News and related publications, since the survey itself was conducted under the auspices of the ACWF.

This is not to deny that representations of women like Tang Shengli in both the China Women's News and the broader Chinese media are frequently didactic and ascribe little if no agency to rural migrant women workers (Sun, W. 2004: 109-28). Nor is it to deny that the ACWF's official adherence to Marxist-style conceptions of prostitution as a reflection of the feudal-patriarchal oppression of women, exacerbated by the introduction of market-mechanisms, following the CCP's contention that China has only just entered 'the primary stage of socialism', has left them unable to conceive of women-in-prostitution as anything other than 'victims' or women who have been seduced by materialistic values (Sun, W. 2002: 188-93; Zheng 2004: 90). It is simply to suggest that the ACWF is not unaware of the problems associated with reinstating traditional conceptions of the 'virtuous (Chinese) woman', as demonstrated by the decision of the China Women's News to follow its media campaign on the 'Tang Shengli Incident' with coverage of another victim of deceptive recruiting for sexual services-Liu Yanhua.

\section{Publicizing the 'Liu Yanhua incident'}

According to a former journalist with the ACWF, the editorial staff at the China Women's News made an executive decision to follow their media campaign on the 'Tang Shengli Incident' with what resulted in 29 reports on the 'Liu Yanhua Incident', a case that coincided with the launch of a nationwide police-led campaign against the kidnapping of and trafficking in women and children on 1 April 2000 (Wu 2003). Like Tang Shengli, Liu Yanhua had left her native village following the promise of a job in a more economically developed part of China only to discover that she had been deceived about the nature of her employment and was expected to 
'work' as a prostitute. Unlike Tang Shengli, who risked her own life rather than be forced into prostitution, Liu escaped from conditions akin to sexual servitude by physically attacking her 'employer'. Hence, media coverage of Liu Yanhua’s story in the China Women's News highlighted the typical details of the case-yet another example of a young rural woman who had been lured and tricked into prostitutionwhilst drawing attention to its atypical finale. The aim of such media coverage was to justify Liu's violent response, not only by suggesting that she had acted in selfdefence in circumstances of extreme duress, but also by implying that it was necessitated by the existence of local-government complicity in the running of prostitution businesses, and the absence of enforceable legal protections for victims of trafficking and violence against women (Wu 2003). To underscore the latter point, the China Women's News drew public attention to the fact that the incident took place in accommodation rented from local court authorities (Deng and Liu 2000).

The 'Liu Yanhua Incident' made national headlines on 27 March 2000 when the China Women's News printed a front-page article written by Deng Xiaobo, an ACWF reporter, and Liu Hongyi, an independent journalist, in conjunction with a letter written by Liu Yanhua's father on 3 March to the Hainan Provincial Government and the National People’s Congress begging legal clemency for his daughter (Deng and Liu 2000). According to these reports, in late October or early November 1999, a 43year-old woman named Tang Xi'er had returned to her native village in Yongxing County, Hunan Province, ostensibly to recruit service personnel for a hotel that she had established in Haikou City, Hainan Province. Persuaded by the offer of 800 yuan per month, plus accommodation and food, 17-year-old Liu Yanhua and several other young women left for Haikou with Tang. Liu found this offer attractive because she had already left school in order to work and help finance her brother's schooling (Tiannan 2004). However, on the evening they arrived, Liu was raped by one of Tang's 'bodyguards', a man named Chen, and forced to service male clients at local hotels and residential homes on a regular basis thereafter (Deng and Liu 2000).

As with Tang Shengli, the article in the China Women's News indicated that Liu's recruiters had used a variety of measures to ensure the compliance of Liu Yanhua and other young women in acts of sexual exploitation. Most notably, Tang Xi'er took away their personal identity cards, demanded a monthly commission or 'receiving 
customer fee' of 2,500 yuan, and forced them to sign promissory notes stating that they already owed her expenses of several thousand yuan for travel, food, and accommodation (Deng and Liu 2000). Those women who failed to pay their monthly commission were beaten and berated by Tang or one of her accomplices. Tang Xi'er also told the women that she would inform members of their native village of their involvement in prostitution, if they attempted to leave (Zhao 2000). This threat of public shaming proved effective. Liu Yanhua fled back to her home in January 2000, but returned when Tang Xi'er telephoned Liu's neighbour and told Liu that she would reveal her involvement in prostitution, if she did not return to Haikou immediately. Liu later stated that she had returned to Haikou because she did not want to destroy her personal reputation and shame her parents (Zhao 2000). This revelation underscores the high value that continues to be placed on pre-marital female chastity in China, particularly in rural regions, even though that value is increasingly at odds with actual social practice.

Unlike its coverage of the 'Tang Shengli Incident', the China Women's News stressed that Liu Yanhua was a victim of sexual exploitation and violence, even though she had acted as a seller of commercial sexual services for several months. Following her return to Haikou, Liu had continued to 'work' for Tang Xi'er until she contracted a sexually transmissible infection (STI) and refused to further service any clients (Deng and Liu 2000). Tang subsequently informed Liu that she would have to pay a 'training and reception' fee of 12,000 yuan if she intended to stop 'working' for her. On the evening of 24 February 2000, Liu asked another young woman to return a loan of 400 yuan so that she could go to see a doctor and look for independent accommodation and alternative work. When Tang overheard this request, she told Liu that she should service male clients if she wanted money. Later that same evening, a reportedly desperate Liu grabbed a cleaver and attacked Tang (possibly when she was sleeping), striking her repeatedly and causing serious injuries to her hands and face (Tiannan 2004). Liu then ran out of Tang's rental accommodation, which was shared by all of the women Tang had recruited, and used a public telephone to call emergency services, saying: 'I’ve killed someone; come and arrest me'. Liu Yanhua later told the Chinese police that her motives were clear: Tang Xi'er had ruined her life and she wanted to kill her (Deng and Liu 2000; Tiannan 2004). 
At this point, the story of Liu Yanhua becomes fused to the story of Liu Hongyi (hereafter Hongyi), an independent journalist who first stumbled upon the case during a family holiday with his wife and child in Haikou (Liang 2005). Originally also from Hunan Province, Hongyi heard about Liu Yanhua from a local resident on the morning after the incident took place. He proceeded to investigate the story by going to the nearby site and discovered that a further 10 young women, and a 12-year-old girl, were staying at the premises that Tang Xi'er had rented from the Yangpu local court. Upon hearing their respective stories, Hongyi and his wife took the 11 young women under their own personal care, taking them to a local medical centre to be treated for STI's and offering them accommodation in their holiday home. Hongyi then traveled to Liu Yanhua's native home to conduct further investigations and apprise Liu's family of the situation. With Hongyi’s assistance, Liu's father composed a letter pleading legal clemency for his daughter. This letter was presented along with Hongyi's report on the case to representatives of the ACWF in Hainan and Hunan; and, subsequently, to representatives from the Hainan Provincial Government and the National People's Congress (Deng and Liu 2000). These actions culminated in the publication of the previously mentioned front-page article in the China Women's News and attracted national television and print media coverage of the case proceedings, with representatives from more than 40 news agencies attending (Liang 2005).

As with Tang Shengli, media coverage of the 'Liu Yanhua Incident' in the China Women's News aimed to secure legal justice for Liu, construed as both a victim of sexual exploitation and a socially disadvantaged person. On 31 March 2000, Liu Yanhua was formally arrested on the criminal charge of attempted murder, based on her verbal confession that she had intended to kill Tang Xi'er (Deng and Liu 2000; Zhao 2000). Lawyer, Li Wuping, who agreed to represent Liu pro bono, successfully defended this charge, arguing instead that Liu should be tried for malicious assault, not only because she was under 18 years of age and had turned herself into the police, but also because she had been harmed and deprived of her freedom, and therefore acted under duress and in self-defence (Zhao 2000). Representatives from the ACWF in Yongxing County also presented guarantees to the effect that they would ensure Liu’s good behaviour upon her release (Deng Xiaobo 2000b). Liu Yanhua accordingly was sentenced on 13 July to two years imprisonment, suspended for three 
years, for malicious assault and ordered to pay Tang Xi'er 16,000 yuan in medical expenses (Liang 2005). Based on the testimonies of other women who voluntarily presented themselves at the local police station to give evidence that they had been tricked and then forced into prostitution, Tang eventually was sentenced to five years jail for the crime of luring, accommodating and introducing others into prostitution (Deng Xiaobo 2000a, 2000b). An additional five people were charged as Tang’s accomplices: but, only three were arrested, with two people absconding, including the man named Chen who was charged with rape (Deng Xiaobo 2000a, 2000b). Hence, while some commentators expressed satisfaction with the lenient sentence meted to Liu, they also expressed dissatisfaction over the fact that Tang Xi'er was not sentenced according to the more serious criminal charges of trafficking in women for the purposes of forced prostitution (Xiao 2000).

Although the involvement of the ACWF ensured that Liu Yanhua's conviction for attempted murder was quashed, her story continued to attract media publicity throughout 2000/01 and, once again, in 2004/05, because of allegations of localgovernment corruption and complications associated with the legal resolution of the case as a whole. For instance, Tang Xi'er originally was released from hospital and police custody on 16 March 2000 due to lack of evidence against her, and she proceeded to resume residence in the property rented from court authorities. Liu's father, and media reporters alike, promptly accused local government authorities of refusing to follow-up the case against Tang due to the existence of corruption (Deng and Liu 2000; Xiao 2000). Accusations of local government complicity in the act of running or ignoring the existence of prostitution businesses were further whetted by the fact that, on 8 April 2000, the Hainan Provincial Government asked the ACWF and central government authorities to halt the media blitz on Liu Yanhua's case because it was ruining Hainan's reputation as a tourist destination (Tiannan 2004). As with the 'Tang Shengli Incident', therefore, the China Women's News was pressured to ‘drop' Liu Yanhua’s story on the grounds that media coverage was damaging broader social interests by hindering the all-important task of developing the local economy.

Pressure from local government authorities in Hainan for the ACWF to halt media coverage of the 'Liu Yanhua Incident' proved to be more acute than pressure from 
Sichuanese authorities over the 'Tang Shengli Incident', as indicated by the fact that Hongyi was harassed and made the target of a smear campaign for his role in breaking the story (Tiannan 2004). Following his initial investigations, Hongyi received threatening phone calls and was stalked by several of Tang Xi'er’s accomplices. He was also brought in for informal but hostile questioning by the Haikou police and required to demonstrate his media accreditations. Then, on 12 July 2000, the day before the court was to reach a verdict on the charges against Liu Yanhua, the Hainan Daily, a local government newspaper with a circulation of 150,000 copies, ran an editorial report that accused Hongyi of being a 'fake journalist' who had made up stories to misguide the public, cause trouble for the police, and damage the reputation of the province (Liang 2005; Tiannan 2004). These accusations resulted in Hongyi becoming the subject of formal investigations by the Haikou police. In the face of such pressure, Hongyi suffered a nervous breakdown and, in August 2000, was institutionalised for rehabilitative treatment. His wife, Cai Jinwen, with the help of various media and legal representatives from the ACWF and the National People's Congress, then commenced a three-year-long legal battle to have Hongyi's reputation reinstated (Liang 2005). Despite the lodging of an estimated 104 appeals, Cai successfully sued the Hainan Daily for defamation of character and damages of 700,000 yuan; and went on to sue a supreme-court judge for deliberately delaying the successful resolution of the case, resulting in the judge's dismissal for malpractice in November 2004 (Liang 2005).

The protracted nature of the legal resolution of the 'Liu Yanhua Incident' highlights the obstacles faced by defenders of victims of forced prostitution, irrespective of whether the women involved are constructed as hapless victims of poverty and exploitative traffickers or as partially empowered agents. In doing so, it underscores the difficulties faced by promoters of national policy. Despite the PRC's theoretical commitment to abolishing the resurgent prostitution industry, it appears that the ACWF's efforts to garner public support for this official policy goal are often conducted without explicit 'top-level' support and in the face of local government opposition.

\section{Conclusion}

The stories of Tang Shengli and Liu Yanhua are marked by a number of similarities. 
Both women were victims of unscrupulous recruiters who sought to profit from the exploitation of the forced prostitution of others. Both cases were made the explicit focus of media campaigns initiated by the ACWF designed to promote a greater awareness of the issues associated with the deceptive recruiting of women for sexual services among the general community; to realize legal and material aid for the women involved; and to highlight the need for legislative and other reforms in order to protect and promote women's rights and interests (Wu 2003). Both cases were also accompanied by local government calls for the ACWF to halt such campaigns, on the grounds that media coverage was destroying the reputation and hence the healthy development of local economies. In addition, both cases were accompanied by problems associated with their successful legal resolution. These problems were related not only to the successful prosecution and appropriate punishment of perpetrators of violence against women, but also to the existence of local-government quiescence with regard to the existence of prostitution businesses, and even to accusations of local-government complicity in the running of such businesses. Justice for Tang Shengli and Liu Yanhua alike was only achieved through the active involvement of members of the ACWF and their coordination with both other government organizations and the Chinese media.

Despite these commonalities, the 'Tang Shengli Incident' and the 'Liu Yanhua Incident' are distinguished not only by the different nature of their denouement for the individual women concerned, but also by the fact of Liu's ongoing involvement in prostitution flowing from her rape and temporary submission to acts of physical and verbal violence. Unlike Tang Shengli, the story of Liu Yanhua highlights some of the problems that accompany the successful resolution of cases of trafficking in women for the purposes of forced prostitution, flowing from what is often construed as the active complicity of such women in the creation and perpetuation of their situation. Like Tang Shengli, Liu Yanhua may have been a naive rural maiden when she left with Tang Xi'er to work in Haikou, but this demonstrably was not the case when she first attempted to leave prostitution by returning to her native home. Moreover, even though Liu's eventual return to Haikou was achieved through threats of public shaming, the fact that Liu had been able to return to her native village in the first place, and had money to offer other women in the form of a loan, suggests that she had some freedom of movement and some degree of financial autonomy. In defending 
Liu Yanhua, therefore, the ACWF was far from promoting a Tang Shengli-style 'chastity heroine'. On the contrary, the very nature of the ACWF's defence of Liu Yanhua, encapsulated in media reports entitled 'Is it Criminal to Use Violence to Combat Violence?' (Wu 2003), presents a different model of female agency from that captured in Tang Shengli's claim that, as an 'old-fashioned girl', she would rather die than engage in prostitution (Tan 1998).

Nevertheless, the China Women's News continued to present Liu Yanhua as an agentful-victim of domestic trafficking for the purposes of forced prostitution for three good reasons. First, Liu initially had been deceived about the nature of her employment. Second, Tang Xi'er had proceeded to exploit Liu through acts of violence and coercion. Finally, Tang Xi'er effectively had exerted rights of ownership over Liu's labour, and thereby placed her in a position of enforced sexual servitude, through the imposition of a debt-contract. The ACWF's defence of Liu Yanhua thus opens the space for public recognition in China of the fact that women who consent to work in the sex industry may still be victims of sexual exploitation and violence. This understanding usefully foregrounds the issue of violence against women and questions the egregious dichotomy between 'the whore' and 'the virtuous woman'the woman who supposedly 'gets what she deserves' as opposed to the woman who merits public sympathy and help—even though it fails to displace that dichotomy. It suggests that that the sexual conduct of women in cases of deceptive recruiting for sexual services is not an appropriate target of media concern. Rather, the media should seek to ensure justice for the women involved in such cases by directing its attention to those who organize and create the demand for commercial sexual services.

As Hong Zhaodi reportedly said: 'China does not need female chastity martyrs; this tragedy should not have happened in the first place' (Zhang 2004). This is a statement with which members of the ACWF indubitably concur, even though their ongoing support for the PRC's official policy of banning prostitution recently has been called into question. In keeping with the pro-sex work lobby of the international feminist movement, many commentators now argue that decriminalization, i.e., removing the voluntary prostitution transaction from the purview of the Chinese system of administrative sanctions, constitutes a preferable policy because it will not only 
empower women-in-prostitution as workers, but also limit corruption, facilitate HIV/AIDS prevention, and enable the Chinese police to focus their resources on the problems of trafficking and forced prostitution (Zhang Heqing 2006, 139-158).

Conversely, in keeping with feminist NGOs who lobby for the abolition of prostitution, other commentators contend that China's governmental authorities should turn a 'blind eye' to the activities of female sellers of sex, whilst making it a punishable offence to obtain casual sexual services against payment as per the policy adopted in Sweden (Zhu 2003). According to promoters of this view, the adoption of such an approach will not only limit the widespread expropriation of public funds by male government officials to buy the sexualized services of women, but also reduce the problem of forced prostitution by enforcing the legal and social unacceptability of sexual exploitation (Zhu 2003).

While the question of which side of the 'feminist prostitution wars' the ACWF might veer towards remains open to debate, media support for, or criticism of, the organization's promotion of Tang Shengli and other victims of forced prostitution is unlikely to halt the occurrence of further incidences while the inequalities and exploitation associated with the rapid development of China's economy remain unresolved. The widespread nature of such problems is indicated by the fact that a group of migrant male workers threatened to jump from a construction building in 2003 to protest the lack of payment of their wages (Wu 2003). Much as some women will continue to enter prostitution to make money since their bodies constitute their only form of available capital, other women will continue to say 'no' to the existence of forced prostitution in the form of the embodied protest, 'over my dead body'.

\section{Reference list}

1997 Criminal Code of the People's Republic of China, 1998, trans. Wei Luo, W.S. Hein and Co., Buffalo, New York.

Bo Wei 2001, Nütong — bugai hushi de zhuti [Female Children-A Subject That Should Not Be Ignored], Zhongguo funü bao, 22 May [Online]. Available: http://www.genderwatchina.org/pages/shownews.asp?id=614 [Accessed 30 October 2006].

Cai Min and Yuan Yiheng 2005, 'Anhui nühai ningsi bu maiyin tiaolou yiyuan tigong mianfei zhiliao' [A Hospital Offers Free Treatment to the Anhui Woman Who Jumped From a Building Rather Than Sell Sex], Xinxi shibao, 11 Mar.

Cai Yipeng, Feng Yuan and Guo Yanqiu 2001, 'The Women’s Media Watch Network', in Chinese Women Organizing: Cadres, Feminist, Muslims, Queers, 
eds. Hsiung et al., Berg Press, Oxford and New York, 209-26.

Dai Xianjian and Liu Yuexiang 2000, 'Beibi maiyin shiwusui xiangmei qingji tiaoxia wulou’ [A Fifteen-year-old Hunanese Girl Jumps From the Fourth Floor of a Building Rather Than Be Forced Into Prostitution] [Online], 21 Nov. Available: http://www.sina.com.cn/s/148197.html [Accessed 4 Nov. 2004].

Deng Hongyang 2001, 'Chongqing nongjianü Dong Shujun zhan qilaile’ [Dong Shujun, the Rural Woman From Chongqing, Stands On Her Own Two Feet Again] Fazhi ribao, 12 July.

Deng Xiaobo and Liu Hongyi 2000, 'Xian huokeng xiangmeizi daopi nülaoban fen shangshu liufu jihu jiu nüer: ming' an fasheng zai fayuan chuzu wu' [A Hunanese Girl Knifes Her Female Boss to Escape From Hell: Her Father Writes a Letter Appealing for Help; the Case of Attempted Homicide Took Place in Accommodation Rented From a Law Court], Zhongguo funü bao, 27 Mar., 1.

Deng Xiaobo 2000a, 'Haikou jingfang chachu zhongda anzhong an' [Haikou Police Investigate the Case Within the Main Case], Zhongguo qingnian bao, 22 April. 2000b, 'Shaonü kanshang baomu an zouchu panjue' [Court Sentences the Young Woman Who Knifed Her Boss], Zhongguo qingnian bao, 12 Aug.

Engels, F. 1972 (1884), The Origin of the Family, Private Property and the State, International Publishers, New York.

Fan Jingyi 2002, 'Zhuazhu zhongdian nandian shixian xin de tupo-zai quanguo renda xinwen xuanchuan ganbu peixun he yantaoban shang de jianghua' [Grasping the Key and Difficult Issues and Making a Breakthrough-a Talk on the National People's Congress News and Public Information Office's Training and Discussion Class for Cadres (Synopsis)], Zhongguo renda xinwen, 21 May [Online]. Available:

http://zgrdxw.peopledaily.com.cn/gb/paper6/16/class000600004/hwz209237.ht m [Accessed 1 Jun. 2005].

Gaetano, A.M. and Jacka, T. (eds) 2004, On the Move: Women in Rural-to-Urban Migration in Contemporary China, Columbia University Press, New York.

Gong Zheng 2002, 'Shaonü cong binguan jiulou tiaoxia shenwang beibi maiyin tiaolou haishi zisha?' [A Young Woman Dies After Jumping From the Eighth Floor of a Hotel Building: Is Jumping From a Building to Avoid Being Forced Into Selling Sex Equivalent to Committing Suicide?], Chutian jinbao, 20 March.

‘Guangzhou lienü Liu Qinqin zuo dedao lianhe fayuan’ [Guangzhou’s Lienü, Liu Qinqin, Obtained Combined Legal Aid Yesterday] 2005, Xinxi Shibao, 10 August [Online]. Available: http://www.gzpf.gov.cn [Accessed 15 Aug. 2006].

He Dongwen, 1998, “'Sanpei” peishui?’ [Who Do 'Hostesses' Accompany?], Zhongguo funü bao, $10 \mathrm{Feb}$.

'Historic Liberation of Chinese Women' 2000, Chapter 1 of a Chinese government white paper on the position of Chinese women [Online]. Available: http://www.peopledaily.com.cn/english/whitepaper/8(1).html [Accessed 10 April 2000].

Hou Jiangang 2004, ‘Tang Shengli jiehunle’ [Tang Shengli Gets Married], Zhongguo funü bao, 19 Jan.

Hsiung, P.C., Jaschok, M., and Milwertz, C. (eds) with Chan, R. 2001, Chinese Women Organizing: Cadres, Feminist, Muslims, Queers, Berg Press, Oxford and New York.

Jeffreys, E. 2004, China, Sex and Prostitution, RoutledgeCurzon, London, New York. Jiang Jingen. 1998, 'Club Boss Gets Five Years in Sex Case', China Daily, 12 Oct., 3. 'Jiuzhi tekun bingren: 15 jia yiyuan jüshou gongshang jiuzhi ji' 2005, [Treating and 
Curing Patients Who Are Experiencing Economic Hardship: 15 Hospitals Get Together to Come Up With a Plan], Guangzhou ribao, 1 March.

Li Hengjuan and Wang Xi 2003, 'Ni dui nüxing liaojie duoshao? Zhendui nüxing de diaocha’ [What Do You Really Know About Women? A Survey On Women], Renmin ribao (Overseas edition), 18 Jan.

Li Ling and Li Xingdian 2004, 'Liang lienü beibi maiyin ningsibucong cong silou zongshen tiaoxia yise yishang' [Two Young Women Who Would Rather Die Than Be Forced Into Prostitution Jump From the Third Floor of a Building: One Is Dead, the Other Injured], Sanxiang dushi bao, 27 Mar.

Li Xiaobo 2002, 'Liang shaonü jüdang sanpeinü bukan laoban weibi tuichuang tiaolou' [Two Young Women Refuse to Become Hostesses: Unable to Put Up With Any More Pressure From Their Boss, They Open a Window and Jump From the Building], Tianfu zaobao, 22 Nov.

Li Yinhe 2005, 'Woguo yinggai ba maiyin dang daode wenti chuli’ [China Should Handle Prostitution as a Moral [not Legal] Issue], Jinyangwang [Online]. Available: http://www.yfs.gov.au, [Accessed 14 May].

Lian Hongyang 2002, 'Lienü fei tiaoluo buke ma?' [Do Female Chastity Martyrs Have to Jump Out of Windows?], Dongfangwang [Online], 30 Dec. Available: http://www.northeast.com.cn/rdts/80200212300392.html [Accessed 13 Aug. 2004].

Liang Jiangsheng (ed.) 2005, 'Ruo ruo Xinjiang nüzi gaodao fayuan yuanzhang’ [A Meek Woman From Xinjiang Sues a Supreme-court Judge], Xinjiang dushi bao, 10 Jan.

‘Lienü Tang Shengli Chengdu xinhun’ [Chengdu’s Newly-wed Female Chastity Martyr, Tang Shengli] 2004, Sichuan nongming ribao, 31 Jan., 1.

Lin Bo 2004, 'Liangnü buyuan maiyin tiaolou shuaicheng zhongshang' [Two Women Are Seriously Injured After They Jump From a Building Rather Than Sell Sex], Xinkuai bao, 10 March.

Liu Xirong and Zhang Yubin 2001, 'Chalou nülaoban qiangpo maiyin shaonü shou cuican tiaolou bao’an’ [A Female Owner of a Teahouse Forces Others Into Prostitution: The Case Is Reported to the Police By a Devastated Young Woman Who Jumped From a Building], Huashang bao, 7 Nov.

Lü Pin 2001, 'Yige celue wenti' [An Issue of Strategy], China-woman.com [Online], 18 Aug. Available: http://www.chinawoman.com/gb/2001/08/16/zgfnb/fnqy/2.html [Accessed 2 Dec. 2003].

Meng Luyan 2000, 'Laoban qiangpo maiyin lienü ningsibucong zongshen cong sanlou tiaoxia’ [Boss Forces Others Into Prostitution: A Female Chastity Martyr Jumps From the Second Floor of a Building, Preferring to Die Rather than Submit] Zhejiang qingnian bao, 28 Nov.

Pan Suiming 2003, “'Lienü” bei shenme suohai?’ [What Harms 'Female Chastity Martyrs'?], Institute of Sexuality and Gender, Renmin University of China [Online], 4 Nov. Available: http://www.sexstudy.org/article.php?id=269 [Accessed 16 June 2004].

Pu Songzhu 2004, 'Shijiusui shaonü zao sanming nanzi weibi maiyin shisibucong tiaoxia liulou' [A 19 Year Old Girl Who Was Forced Into Prostitution By Three Men Jumps From the Fifth Floor of a Building, Preferring to Die Rather Than Submit], Guangzhou ribao, 7 March.

Quanguo renda changwu weiyuanhui [Standing Committee of the National People's Congress] 1991, Guanyu yanjin maiyin piaochang de jueding he guanyu yancheng guaimai bangjiafunü, ertong de fanzui fenzi de jueding shiyi [An 
Explanation of the Decision on Strictly Forbidding the Selling and Buying of Sex and the Decision on the Severe Punishment of Criminals Who Abduct and Traffic in or Kidnap Women and Children], Zhongguo jiancha chubanshe, Beijing.

Quanguo renda changwu weiyuanhui [Standing Committee of the National People's Congress] 2005, Zhonghua Renmin Gongheguo Zhi'an Guanli Chufa Fa [Security Administration Punishment Law of the People's Republic of China]. Available: http://news.xinhuanet.com/newscenter/2005-08/28/content_3413618.htm

[Accessed 16 November 2006].

Ran Qihu and He Yugu 2004, 'Baomu zongshen tiaolou shisi budang “xiaojie”' [A Maid Jumps From a Building Claiming She Would Rather Die Than Become a 'Hostess'], Hualongwang [Online], 4 June. Available: http://www.cqnews.com.cn/newsview.as?nid=45997 [Accessed 8 June. 2004].

Sheng Dalin 2003, 'Zenyang caineng rang “lienü” shao qilai' [How Can We Reduce the Number of 'Female Chastity Martyrs'?], Dongbei News Agency, 3 Jan.

Starr, J.B. 2001, Understanding China: A Guide to China's Economy, History and Political Structure, Profile Books, London.

Su Heng 2001, 'Shiqisui shaonü beipian maiyin: sanshiba xiaoshi ningsibuchu tiaolou taoli moku' [A 17 Year Old Young Woman Is Tricked Into Selling Sex: After Being Held for 38 Hours She Jumps From a Building Preferring to Die Rather Than Be Held in the Devil's Clutches], Sichuan qingnian bao, 18 March.

Sun Guangxun 2005, 'Feifa laowushichang heyi lüjinbujue' [Why Do Illegal Labour Markets Still Exist?], Rednet.com.cn [Online], 22 Feb. Available: http://hlj.rednet.com.cn/Articles/2005/02/666381.HTM [Accessed 1 June 2005].

Sun, W. 2002, 'Invisible Entrepreneurs: The Case of Anhui Women', Provincial China, 7, 2, 178-95.

2004, 'Indoctrination, Fetishization and Compassion: Media Constructions of the Migrant Woman', in On the Move: Women in Rural-to-Urban Migration in Contemporary China, eds. A.M. Gaetano and T. Jacka, Columbia University Press, New York, 109-28.

Tan, H 1998, 'From a Tragic Fall, She's Now Walking Tall', Enablenet-News [Online], 6 July. Available: http://www.dpa.org.sg/news/news_july_1998-1.html [Accessed 5 May 2004].

Tiannan Haibei 2004, 'Jizhe zhangyizhiyan zao wuxian: lüshi kuasheng yuanzhu xi yuanwang’ [A Reporter Is Slandered for Helping the Needy: A Lawyer From Another Province Comes to His Aid], Ynet.com [Online], 19 March. Available: http://bbs.ynet.com/cgi-bin/ReadFile?whichfile=575\&typeid=46 [Accessed 5 Oct. 2004].

United Nations 2000, Protocol to Prevent, Suppress and Punish Trafficking in Persons, Especially Women and Children, Supplementing the United Nations Convention Against Transnational Organized Crime, United Nations, New York.

Wan Jun and Liu Fuguo 2004, 'Zhencao yu shengming shu geng zhongyao' [Which Is the Most Important: Chastity or Life?], Sina.com.cn [Online] 2 July. Available: http://www.sina.com.cn/o/2004-07-02/11472970847s.shtml [Accessed 16 Aug. 2004].

Wang Fengbin 1998, 'Xiang “fuwu xiaojie” zhengshui nan zai nali?’ [What’s So Difficult About Taxing ‘Female Service Workers’?], Fazhi ribao, 17 Aug. 1.

Wang Yueguo 2003. 'Guanyu meiti jiuzhu de fenxi yu sikao' [A Consideration of the Media’s Role In Rescuing Those In Danger], Zijin.net [Online], 5 May. 
Available: http://www.zijin.net/gb/content/2003-05/05/content_295...

[Accessed 6 Oct. 2004].

Wang Xiaobo 2002, ‘Funü fazhan yu chuanmei de zeren’ [Women’s Development and Media Responsibility], Zhongguo funü bao, 26 Mar.

'Women’s Lobby Tackles Bar Sex’ 1999, South China Morning Post, 4 March.

Wu Jieling 2003, 'Cong liangge weiquan anli kan shendu xinwen baodao de cehua'

[Two Cases On the Protection of Women's Rights and Interests Show Us How

to Plan In-Depth News Reports], Dongfang zaobao, 19 Sep.

Xiao Lang 2000, “"Luobo” yu "ni”” [Turnips and Soil], Shidai chao [Online].

Available: http://www.people.com.cn/GB/paper83/1059/154635.html [Accessed 21 Jan. 2005].

'Xinhua xin ciyu cidian ye "bao" ernai' 2002, [The Xinhua New Dictionary of Chinese Phrases Also Includes 'Second Wives']. Lianhe zaobao, 26 Dec.

Zhang Heqing. 2006. 'Female sex sellers and public policy in the People's Republic of China, in Sex and Sexuality in China, ed. E. Jeffreys, RoutledgeCurzon, London, New York, 138-158.

Zhang Xiao 2004, 'Hong Zhaodi: xiwang bu zaiyou “lienü”’ [Hong Zhaodi: Let’s Not Have Any More ‘Female Chastity Martyrs’], Wenzhaibao, 3 June.

Zhao Shilong 2000, 'Maiyinnü daopi laobao: qing yu fa jiduo xixu’ [A Female Sex Seller Knives a Brothel Organizer: The Contradiction Between Law and Human Feelings], Wenzhaibao, 11 May.

Zheng, Tiantian 2004, 'From Peasant Women to Bar Hostesses: Gender and Modernity in Post-Mao Dalian', in On the Move: Women in Rural-to-Urban Migration in Contemporary China, eds. A. Gaetano and T. Jacka, Columbia University Press, New York, 80-108.

Zhongguo kangfu yanjiu zhongxin [Chinese Rehabilitation Research Centre] 2003, 'Kuangfu zhengyi fengxian aixin kangfu zhongxin jiuzhu “sanpeinü” fei yingli jigou gongguan anli' [The Case of a Non-profit Rehabilitation Centre that Helps to Restore Justice for a 'Hostess'] [Online], 13 March. Available: http://market168.8u8.cpm/pral.html [Accessed 12 May 2004].

Zhonghua renmin gongheguo hunyinfa, Zhonghua renmin gongheguo funü quanyi baozhang fa [The Marriage Law of the People's Republic of China and the Law of the People's Republic of China on the Protection of Women's Rights and Interests] 1994, Zhonguo fazhi chubanshe, Beijing.

Zhonghua renmin gongheguo guowuyuan [State Council of the PRC] 1999, Yule changsuo guanli tiaoli [Regulations Concerning the Management of Public Places of Entertainment], Wenhua chubanshe, Beijing.

Zhou Shijun 2003, “'Lienü” baodao weihe bushou nüxing huanying?' [Why Are Reports On 'Female Chastity Martyrs’ Not Welcomed By Women?], Renminwang [Online], 2 Jan. Available: http://past.people.com.cn/GB/guandian/30/20030102/9 [Accessed 13 Aug. 2004].

Zhu Jiaolong 2003, ‘Saohuang yinggai zhua jinü haishi piaoke?’ [Should Campaigns Against Prostitution and Illegality Target the Sellers or Buyers of Sex?], Nanfang dushi bao, 2 Dec. 